\title{
Quality of life and burden of informal caregivers providing care for patients with low function agility in the home environment
}

\author{
AGNIESZKA BARTOSZEK ${ }^{1, A, B, D-F}$, EDYTA GAŁĘZIOWSKA ${ }^{1, A, C-F}$, BARBARA ŚLUSARSKA ${ }^{1, A, C-E}$ \\ ORCID ID: 0000-0003-0974-0761 \\ HANNA KACHANIUK ${ }^{1, D}$, KATARZYNA PIASECKA ${ }^{1, C, F}$, ALINA DELUGA $^{1, D, E}$ \\ RENATA DOMŻAt-DRZEWICKA ${ }^{2, \mathrm{~F}}$, KATARZYNA KOCKA ${ }^{1, \mathrm{~B}}$, GRZEGORZ NOWICKI ${ }^{1, \mathrm{~B}}$
}

\author{
${ }^{1}$ Department of Family Medicine and Community Nursing, Faculty of Health Sciences, Medical University \\ of Lublin, Poland \\ ${ }^{2}$ Department of Oncology, Faculty of Health Sciences, Medical University of Lublin, Poland
}

A - Study Design, B - Data Collection, C - Statistical Analysis, D - Data Interpretation, E - Manuscript Preparation, F - Literature Search, G - Funds Collection

Summary Background. Providing care to patients with low function agility in the home environment becomes a burden and leads to the worsening of the informal caregiver's quality of life.

Objectives. Aim of the research was to assess the quality of life of informal caregivers in the context of their burden linked to the care provided to chronically ill patients with low function agility in the home environment.

Material and methods. Research was conducted in five public healthcare facilities, from September 2016 until February 2017, and included 138 informal caregivers. The WHOQOL-AGE scale was used to assess caregivers' quality of life, and the COPE Index was employed to assessed caregivers' burden.

Results. According to WHOQoL-AGE, the average value of caregivers' quality of life was 70.14 points. Caregivers' burden according to the COPE Index Negative Impact of Care subscale was: $M=11.80$; Positive Value of Care subscale: $M=13.71$; and in Quality of Support subscale: $\mathrm{M}=12.46$. Statistical importance was at $p \leq 0.01$ for WHOQoL-AGE scale, and the burden according to the COPE Index. Conclusions. Informal caregivers' quality of life according to the WHOQoL-AGE scale corresponds significantly with caregivers' burden according to the COPE-Index, in all of the analysed domains. Along with the increase of the negative influence of the care, general quality of life with all its subscales, as well as satisfaction, decreases. Caregivers' quality of life increases along with the increase of the satisfaction connected to the provided care, and with receiving support from informal and formal healthcare. Key words: quality of life, caregivers, home nursing, burnout, psychological.

Bartoszek A, Gałęziowska E, Ślusarska B, Kachaniuk H, Piasecka K, Deluga A, Domżał-Drzewicka R, Kocka K, Nowicki G. Quality of life and burden of informal caregivers providing care for patients with low function agility in the home environment. Fam Med Prim Care Rev 2019; 21(1): 12-16, doi: https://doi.org/10.5114/fmpcr.2019.82972.

\section{Background}

For most caregivers, providing care to the chronically ill with low function agility in the home environment generates burden and negative changes in quality of life (QoL) [1, 2]. Still, in Poland, $75 \%$ of the caregivers, whether formal or informal, feel that they have no choice when it comes to taking responsibility for the patient [3].

In recent years, researchers have begun to pay attention to the informal caregivers who deal with the consequences of providing care to the dependent person [4]. This exacts a toll on their social function and health. In the case of providing care to a patient suffering from Parkinson's disease, an informal caregiver may experience anxiety and depression as a result of the high stress levels connected to care provision [5]; similar effects have been observed in caregivers of patients with Alzheimer disease [6], and chronic mental health illnesses [7]. This diminished quality of life demands the creating of a strategy for social support for informal caregivers, aimed mainly at reducing stress and depression symptoms $[8,9]$.

Quality of life among informal caregivers has its basis in such aspects as self-perception, family relations, the effects of chronic stress, and in coping with this, as well as physical health (e.g. conditions resulting from an overload of musculoskeletal system) and mental health (e.g. depression, anxiety, sleep disorders). Having a disabled, chronically ill or an elderly person in the family always affects the functioning of the whole family, changing its lifestyle, disrupting its balance, and disorganizing its previous functioning. However, the changes in previously fulfilled social roles, professional life, interpersonal relations, as well as the expectations and life plans, affect mainly the main informal caregiver [4].

Informal caregivers' quality of life is tightly linked to their burden $[10,11]$, meaning the physical, emotional, material, and social costs that they must account for when providing the care to a chronically ill member of the family. This can have a subjective character (feeling of burden) and an objective character [12]. It needs to be emphasized that this relation is bidirectional: the burden significantly affects their subjective quality of life, and their stress levels [13]

\section{Objectives}

The aim of the research was to assess the quality of life of informal caregivers in the context of their burden connected to the care provided to chronically ill patients with low function agility in the home environment. 


\section{Material and methods}

Research was conducted in Lubelskie voivodship, in five public healthcare facilities, from September 2016 until February 2017, among 138 informal caregivers providing long-term care to patients in the home environment. Criteria for choosing the caregivers for the research were: fulfilling the role of a family caregiver (providing care to a chronically ill person with physical function impairment according to the Barthel scale of 0-85 points in the home environment), and caregiver's consent to participate in the research.

Two standardised tools were applied, namely WHOQOL-AGE scale, and the COPE Index, as well as an original questionnaire produced in order to gather basic socio-demographic information about the respondents.

The WHOQoL-AGE survey was used to assess caregivers' quality of life. The version of the survey was adapted for use in Polish conditions by a team of researchers from Jagiellonian University and the Medical College of Krakow [14]. Despite the fact that the scale is mainly used to assess the quality of life in older adults, research showed that it can be used in order to assess quality of life of younger people. WHOQOL-AGE survey is an instrument to measure quality of life with 13 positive items. When constructing the original WHOQoL-AGE survey, both classical test theory (CTT), as well as item response theory (IRT) were taken into consideration. A hierarchical structure of the scale was obtained, with one factor of the second order and two factors of the first order. The first factor contained questions from Q1 to Q8 (Subscale F1 - Satisfaction), whereas the second factor included questions from Q9 to Q13, and Q1 (Subscale F2 - Fulfilling of Expectations). The final result is formed as the arithmetic mean of two subscales. WHOQoL-AGE measures quality of life expressed in values between 0 and $100[14,15]$.

The COPE Index questionnaire was used to assess the burden of informal caregivers. It is a screening tool identifying the needs of caregivers and emphasizing a subjective assessment of the caregivers, their situation and the circumstances of care provision. The COPE Index consists of 15 close-ended questions, as well as additional open-ended questions. The posed questions create three subscales, namely Negative Impact of Care (NIoC) - 7 questions with a point range from 7 to 28 points, Positive Value of Care (PVoC) - 4 questions, and Quality of Support (QoS) -4 questions. The last two have subscales with a 4 to 16 point range each. The subscales are concerned with independent care aspects; therefore, they are interpreted separately [16].

The Shapiro-Wilk test was utilized to check if the variables were distributed normally. The overall result of the quality of life scale (WHOQoL-AGE) and the two subscales met the conditions of normal distribution and the results of the scale were presented as a mean, standard deviation, minimum and maximum. The result of the Caregivers of Older People in Europe (COPE Index) deviated from the normal distribution and was presented as median, minimum, maximum; lower and upper quartile. The qualitative variables were presented as numbers and percentages. The Spearman rank correlation was applied to examine the relationship between the quality of life scale and the caregivers' burden scale. Statistical analyses were performed using SPSS 23.0 (SPSS Inc., Chicago, IL, USA). $p$-values of $<0.05$ were considered significant.

All informal caregivers provided written consent to participate in the research, which was carried out in accordance with the requirements of the Helsinki Declaration, and received the positive opinion of the Bioethical Committee of Medical University in Lublin (No KE-0254/13/2016).

\section{Results}

\section{Characteristics of the researched}

\section{Caregivers group}

The research was carried out among 138 caregivers of patients with chronic illnesses and low function agility, staying under long-term care in the home environment. $77.5 \%$ of the group were women. They were people aged 59 to 84 years old, and the average age was 68.57 years $(S D=11.6)$.

The most numerous groups were people aged $66-75$ years (44.2\%) and $59-65$ years (41.3\%). The eldest caregivers among the researched (over 75 years old) constituted $14.5 \%$ of the entire group.

When it comes to the marital status, more than two-thirds of respondents were in a relationship (69.6\%), while $30.4 \%$ were single. Informal caregivers were most often spouses (43.5\%), children $(23.2 \%)$, other relatives $(9.4 \%)$, siblings $(2.9 \%)$ and parents $(1.4 \%)$.

Most caregivers cohabited with the patient in a shared house or a flat $(60.9 \%) ; 11.6 \%$ of the caregivers lived within a 10 minute driving distance, and $10.9 \%$ lived within a distance of a short walk.

Over half of the researched caregivers (55.8\%) had looked after another person beforehand, however, for $44.2 \%$ of the respondents, it was their first experience. Caregivers, on average, spent 36.24 hours weekly on fulfilling their duties connected with their patients ( $S D=41.15$ ).

$52.9 \%$ of the researched are the sole caregiver of patients with low function agility - they do not receive any support. $47.1 \%$ of the surveyed caregivers received support from other people in the form of around 20.78 hours weekly (SD = 26.2).

\section{Patients group}

The average age of the patients staying under the care of informal caregivers was 74.91 (SD = 9.08). Most often, the patients were women (76.5\%), with the assessment according to the Barthel scale ranging from $21-40$ points (45.6\%). Patients scoring $0-20$ points constituted $32.9 \%$ of the group. Patients with moderate function agility (41-85 points) constituted $21.5 \%$ of the group.

The average value on the Abbreviated Mental Test Score (AMTS) was $M=7.78$ (SD = 2.64), whereas on the Geriatric Depression Scale Short Form (GDS-SF) diagnosing the intensity of depression symptoms, $M=7.34(S D=3.10)$. The average duration of patient care was $M=3.59(S D=2.68)$. The surveyed patients were characterized by multimorbidity; the dominant diseases were: atherosclerosis (70.1\%), hypertension (61.3\%), polyarthritis $(42.3 \%)$, diabetes $(22.6 \%)$, ischemic heart disease (16.8\%) and cerebrovascular disease (10.9\%). Multimorbidity is connected with polypharmacy; the average amount of medications taken was $\mathrm{M}=7.9(\mathrm{SD}=2.8)$.

Quality of life and burden of informal caregivers linked to the care provided to patients with function agility deficits

In assessment of WHOQoL-AGE, average value of life quality of the caregivers was 70.14 points (SD $=15.31$ points). In the Satisfaction subscale, the average was 71.11 (SD = 13.88), and in Fulfilling of Expectations subscale, the score was 69.15 points ( $S D=18.55)$. The aforementioned data is presented in Table 1.

Table 2 presents the results of applying the COPE Index and its subscales among the researched caregivers. $57.4 \%$ of the researched caregivers received high scores on the subscale Negative Impact of Care (NloC). Positive Value of Care (PVoC) received an upper range of $59.3 \%$, whereas high Quality of Support (QoS) received only $40 \%$ among all caregivers. 


\begin{tabular}{|l|l|l|l|}
\hline \multicolumn{3}{|c|}{$\begin{array}{l}\text { Table 1. Descriptive statistics of quality of life scale of caregiv- } \\
\text { ers according to WHOQoL-AGE }\end{array}$} \\
\hline & WHOQOL-AGE & $\begin{array}{l}\text { Subscale F1 } \\
\text { Satisfaction }\end{array}$ & $\begin{array}{l}\text { Subscale F2 } \\
\text { Fulfilling of } \\
\text { expectations }\end{array}$ \\
\hline M & 70.14 & 71.11 & 69.15 \\
\hline SD & 15.31 & 13.88 & 18.55 \\
\hline Min-Max & $26.00-96.42$ & $30.76-100.00$ & $15.47-100.00$ \\
\hline
\end{tabular}

$\mathrm{M}$ - arithmetic mean; SD - standard deviation.
Statistical analysis of the relationships between the quality of life results of informal caregivers according to the scale WHOQoL-AGE and their burden according to the COPE Index; and their subscales showed statistical significance at the level $p<0.001$, with a strong correlation of these relationships (Table 3). A strong negative correlation was observed between the subscale NIoC with the general results of quality of life WHQoL-Age, as well as both subscales. In turn, subscales PVoC i QoS had a strong positive correlation with positive values of the quality of life of caregivers both in the overall result of WHOQoL-AGE, as well as with its subscales.

\begin{tabular}{|l|l|l|l|}
\hline Table 2. Descriptive statistics of burden scale according to COPE Index \\
\hline & Negative Impact of Care (NIoC) & Positive Value of Care (PVoC) & Quality of Support (QoS) \\
\hline Me & 11.00 & 14.00 & 13.00 \\
\hline Q1-Q3 & $9.00-14.25$ & $12.00-15.00$ & $11.00-15.00$ \\
\hline Min-Max & $7.00-23.00$ & $7.00-16.00$ & $6.00-16.00$ \\
\hline$n(\%)$ & $7-10$ (lower range) & $4-13$ (lower range) & $4-12$ (lower range) \\
& $64(42.6)$ & $61(40.7)$ & $90(60.0)$ \\
& $11-28$ (upper range) & $14-16$ (upper range) & $13-16$ (upper range) \\
& $86(57.4)$ & $89(59.3)$ & $60(40.0)$ \\
\hline
\end{tabular}

Me - median; Q1 - lower quartile; Q3 - upper quartile.

\begin{tabular}{|l|l|l|l|}
\hline \multicolumn{2}{|l|}{ Table 3. Quality of life according to WHOQoL-AGE versus informal caregivers' burden according to COPE Index } \\
\hline & $\begin{array}{l}\text { Negative Impact of Care } \\
\text { (NloC) }\end{array}$ & $\begin{array}{l}\text { Positive Value of Care } \\
\text { (PVoC) }\end{array}$ & $\begin{array}{l}\text { Quality of Support } \\
\text { (Q.oS) }\end{array}$ \\
\hline WHOQoL-AGE & $-0.668^{*}$ & $0.501^{*}$ & $0.629^{*}$ \\
\hline $\begin{array}{l}\text { Subscale F1 } \\
\text { Satisfaction }\end{array}$ & $-0.607^{*}$ & $0.400^{*}$ & $0.633^{*}$ \\
\hline $\begin{array}{l}\text { Subscale F2 } \\
\text { Fulfilling of expectations }\end{array}$ & $-0.657^{*}$ & $0.528^{*}$ & $0.678^{*}$ \\
\hline
\end{tabular}

${ }^{a}$ rho-Spearman correlation; * statistically significant correlations level of $p<0.001$ (two-tailed).

\section{Discussion}

Patient's disability or other state of being which demands care in the home environment, always changes family function. Caring for a person who is physically disabled and needs help in transference significantly affects caregiver's state of health, especially in the mental sphere, increasing feelings of burden and lowering the quality of life [17].

In our study, caregivers' quality of life was measured using the WHOQoL-AGE assessment, which was designed to ascertain the quality of life of aging populations [18].

Average level of caregivers' quality of life according to WHOQoL-AGE was 70.14, and is higher than in the report of Zawisza et al. [14], in which the general score for WHOQoL-AGE was 58.6. The higher level of $\mathrm{QoL}$ in our research may result from the younger age of the caregivers $(M=68.57)$, than in the research of Zawisza ( $M=76.11$ ). In report of Santos et al. [19], using WHOQoL-AGE in three European countries, with 3,940 Polish people in the study population, the results of QoL were higher in Finland than in Spain and Poland.

The obtained results according to the COPE-Index indicate that $42.6 \%$ of all informal caregivers suffered from a negative overload in relation to care, according to Negative Impact of the Care assessment in the case of a patient with functional deficit. However, $59.3 \%$ of all respondents express their satisfaction measured by the Positive Value of the Care scale, though 60\% chose low help and support according to the Quality of Support. Karczewska and Bien particularly points out the average score in the Negative Impact of Care scale in the group of the patients with dementia. This is at a 11.9 level (SD $=4.2$ ), as opposed to the control group $\mathrm{M}=8.9$ (SD = 2.7) [20]. In contrast, Balducci et al. in a study of 1,000 Polish caregivers, saw an average score in Negative Impact of Care of 9.86 (SD = 3.56), and in Positive Value of Care of 13.91 (SD = 2.18) [16]. Positive Value of Care can be assigned to the feeling of satisfaction of informal caregivers linked to the care provided. In Grochowska's report, most caregivers (39\%), at least sometimes felt satisfaction linked to the provided care - often at $36 \%$, always at $20 \%$, and never felt satisfaction at $5 \%$ [21].

In the review of literature using the COPE-Index scale, there was only one mention concerning using the Quality of Support subscale to assess the correlation to Negative Impact of Care among 100 Polish caregivers [22]. Caregivers that felt well-supported by the family, and well supported in their role as a career, had lower indicators in the Negative Impact of Care subscale.

The assessment of the quality of life of the caregivers in relation to the burden of caregivers in different populations has been well documented [23-26]. In our research, both the overall score and all quality of life domains according to WHOQoL-AGE positively correlated with each subscales of the COPE Index.

Informal caregivers in the home environment experience a worse quality of life, compared to informal caregivers of persons staying under institutionalized care [27-29]. The importance of support for caregivers in the home environment needs to be emphasized in the context of lowering the subjective feeling of burden and the bettering of the quality of life. In our research, $47.1 \%$ of all caregivers reported that they received support from other people. In spite of that, $60 \%$ of our informal caregivers negatively assessed the quality of the support obtained in the Quality of Support subscale (QoS).

Home nurses should fulfil a key role in assessing the needs of informal caregivers and providing support. Such support includes reminding them about the importance of taking care of their own health. Understanding the experience of the caregiv- 
ers might help the family nurses/nurses of long-term healthcare in creating strategies aimed at improving the quality of life of informal caregivers [30].

\section{Limitations of the study}

Our research bears certain limitations, namely, the research participants were chosen purposefully from the community of informal caregivers in the home environment, instead of being chosen randomly. Furthermore, the cross-cutting project of the research, and the conducted analysis of the results, limits its strength of causal inference. In addition, research results are based on a small test group, which may also influence the generalisation of gathered research results. It needs to be emphasized that caregivers expressed satisfaction, because their role was being noticed, and eagerly talked with nurses about the problems they face in their role.

\section{Recommendation for family doctors}

In their practice, general practitioners, when identifying the health problems of chronically ill patients with functional deficits, should also recognize the caregiver and not only focus on the patient. The golden standard of home care should be based on the results of the COPE-Index of a caregiver of a chronically ill patient with functional deficits in order to detect early existing health threats. Recognizing the difficulties of caregivers enables the general practitioners to hold the opportunity to understand caregivers' needs, provide them with adequate support, and thus allow them to more efficiently perform their role as a home caregiver, hence, postponing the need to transfer the patient to institutional care. The caregiver who feels supported has a better sense of quality of life, can also be a medical doctor's partner in providing optimal care for the patient in the home environment.

\section{Conclusions}

1. Informal caregivers' quality of life significantly correlates with their burden according to the COPE-Index in all of the analysed domains.

2. We observed a significant negative correlation between the negative impact of care and the general quality of life of the caregivers and its subscales.

3. Our research shows that with the increase in satisfaction with care and quality of support, both the general level of quality of life and subscales are positively enhanced.

Source of funding: Results prepared in the scope of research project (grant DS-519 Medical University in Lublin). Conflicts of interest: The authors declare no conflicts of interest.

\section{References}

1. Bień B, Wojszel ZB. Poziom niesprawności osób w starszym wieku jako wskazanie do wspierania opiekunów rodzinnych. Gerontol Pol 2008; 16: 25-34 (in Polish).

2. Rachel W, Turkot A. Jak pomóc opiekunom pacjentów z otępieniem w chorobie Alzheimera? Psychoterapia 2015; 1: 59-71 (in Polish).

3. Błędowski P, Maciejasz M. Rozwój opieki długoterminowej w Polsce - stan i rekomendacje. Now Lek 2013; 82: 61-69 (in Polish).

4. Glozman JM. Quality of life of caregivers. Neuropsychol Rev 2004; 14: 183-196.

5. Zhong M, Peppard R, Velakoulis D, et al. The relationship between specific cognitive defects and burden of care in Parkinson's disease. Int Psychogeriatrics 2016; 28: 275-281.

6. Omranifard V, Haghighizadeh E, Akouchekian S. Depression in main caregivers of dementia patients: prevalence and predictors. Adv Biomed Res 2018; 7: 34, doi: 10.4103/2277-9175.225924.

7. Olagundoye $\mathrm{O}$, Akhuemokhan $\mathrm{V}$, Alugo $\mathrm{M}$. Towards caring for caregivers: assessing the burden of care and experience of associative stigma among caregivers of patients with chronic mental illnesses at a mental health care facility in Lagos Metropolis, Nigeria. Fam Med Prim Care Rev 2017; 19: 149-155.

8. Roche L, Croot K, Maccann C, et al. The role of coping strategies in psychological outcomes for frontotemporal dementia caregivers. J Geriatr Psychiatry Neurol 2015; 28: 218-228.

9. García-Alberca JM, Cruz B, Lara JP, et al. Anxiety and depression are associated with coping strategies in caregivers of Alzheimer's disease patients: results from the MÁLAGA-AD study. Int Psychogeriatrics 2012; 24: 1325-1334.

10. Hastrup LH, Van Den Berg B, Gyrd Hansen D. Do informal caregivers in mental illness feel more burdened? A comparative study of mental versus somatic illnesses. Scand J Public Health 2011; 39: 598-607.

11. Ho SC, Chan A, Woo J, et al. Impact of caregiving on health and quality of life: a comparative population-based study of caregivers for elderly persons and noncaregivers. Journals Gerontol - Ser A Biol Sci Med Sci 2009; 64: 873-879.

12. Rachel W, Datka W, Zyss T. Obciążenie opiekunów pacjentów z otępieniem w chorobie Alzheimera. Gerontol Pol $2014 ; 22: 14-23$ (in Polish).

13. Golińska P, Bidzan M. Poczucie obciążenia opiekunów osób z chorobą Parkinsona. Przegląd badań. Geriatria 2017; 11: 22-28 (in Polish).

14. Zawisza K, Gałaś A, Tobiasz-Adamczyk B. Validation of the Polish version of the WHOQoL-AGE scale in older population. Gerontolgia Pol 2016; 24: 7-16.

15. Caballero FF, Miret M, Power M, et al. Validation of an instrument to evaluate quality of life in the aging population: WHOQoL-AGE. Health Qual Life Outcomes 2013; 11: 177.

16. Balducci C, Mnich E, McKee KJ, et al. Negative impact and positive value in caregiving: validation of the COPE index in a six-country sample of carers. Gerontologist 2008; 48: 276-286.

17. Markowitz JS, Gutterman EM, Sadik K, et al. Health-related quality of life for caregivers of patients with Alzheimer disease. Alzheimer's Dis Assoc Disord 2003; 17: 209-214.

18. Fang J, Power M, Lin Y, et al. Development of short versions for the WHOQoL-OLD module. Gerontologist 2012; 52: 66-78.

19. Santos D, Abad FJ, Miret M, et al. Measurement invariance of the WHOQoL-AGE questionnaire across three European countries. Qual Life Res 2018; 27(4): 1015-1025.

20. Karczewska B, Bień B. Opiekunowie rodzinni osób starszych z otępieniem lub zaburzeniami poznawczymi w Polsce - czynniki ryzyka obciążenia opieką. Gerontol Pol 2012; 20(2): 59-67 (in Polish).

21. Grochowska J. Poczucie satysfakcji oraz obciążenia obowiązkami nieformalnych opiekunów osób starszych w zależności od poziomu sprawności podopiecznych. MONZ 2014; 20: 46-50 (in Polish).

22. Bień-Barkowska K, Doroszkiewicz H, Bień B. Silent strain of caregiving: exploring the best predictors of distress in family carers of geriatric patients. Clin Interv Aging 2017; 12: 263-274. 
23. Li J, Lambert CE, Lambert VA. Predictors of family caregivers' burden and quality of life when providing care for a family member with schizophrenia in the People's Republic of China. Nurs Heal Sci 2007; 9: 192-198.

24. Faronbi JO, Olaogun AA. The influence of caregivers' burden on the quality of life for caregivers of older adults with chronic illness in Nigeria. Int Psychogeriatrics 2017; 29: 1085-1093.

25. Parekh NK, Shah S, Mcmaster K, et al. Effects of caregiver burden on quality of life and coping strategies utilized by caregivers of adult patients with inflammatory bowel disease. Ann Gastroenterol 2017; 30: 89-95.

26. Ogunlana MO, Dada OO, Oyewo OS, et al. Quality of life and burden of informal caregivers of stroke survivors. Hong Kong Physiother J 2014; 32: 6-12.

27. Rodrigues AM, Ferreira PL, Ferré-Grau C. Providing informal home care for pressure ulcer patients: how it affects carers' quality of life and burden. J Clin Nurs 2016; 25: 3026-3035.

28. Bleijlevens MHC, Stolt M, Stephan A, et al. Changes in caregiver burden and health-related quality of life of informal caregivers of older people with dementia: evidence from the European Right Time Place Care prospective cohort study. J Adv Nurs 2015; 71: $1378-1391$.

29. Gaugler JE, Mittelman MS, Hepburn K, et al. Predictors of change in caregiver burden and depressive symptoms following nursing home admission. Psychol Aging 2009; 24: 385-396.

30. Santos-García D, de la Fuente-Fernández R. Factors contributing to caregivers' stress and burden in Parkinson's disease. Acta Neurol Scand 2015; 131: 203-210.

Tables: 3

Figures: 0

References: 30

Received: 8.06.2018

Reviewed: 19.06 .2018

Accepted: 5.09.2018

Address for correspondence:

Agnieszka Bartoszek, MD, PhD

Zakład Medycyny Rodzinnej i Pielęgniarstwa Środowiskowego

Wydział Nauk o Zdrowiu

Uniwersytet Medyczny w Lublinie

ul. Staszica 4-6

20-081 Lublin

Polska

Tel.: +48 660111697

E-mail: agabartoszek@wp.pl 